\section{'Hernandez' Sweetpotato}

D.R. La Bonte ${ }^{1}$, W.A. Mulkey ${ }^{2}$, C.A. Clark ${ }^{3}$, L.H. Rolston ${ }^{4}$, J.M. Cannon ${ }^{5}$, P.W. Wilson ${ }^{6}$, and P.C. St. Amand ${ }^{7}$

Louisiana Agricultural Experiment Station, Louisiana State University Agricultural Center, Baton Rouge, LA 70803

Additional index words. Ipomoea batatas, vegetable breeding, disease resistance

'Hernandez' sweetpotato [Ipomoea batatas (L.) Lam.] was developed by the Louisiana Agricultural Experiment Station. This late-sizing cultivar has high yield and excellent baking and processing qualities in combination with resistance to diseases.

\section{Origin}

'Hernandez', previously tested as L82-66, originated from the breeding program of Teme Hernandez as an open-pollinated seedling of L70-323 polycrossed in 1981. The female lineage of L70-323 is L63-217 and L41-21. L41-212 originated from a cross of 'Mameyita' $\times$ L4-6.

\section{Description}

'Hernandez' has moderately long purplestemmed vines. Leaves are cordate to slightly lobed with purplish abaxial venation. The petiole is purple at the base and at the junction with the leaf axis. Storage roots are fusiform, lightly grooved, and red skinned. The cortex is intermediate in thickness and the flesh is a uniform deep orange. It has excellent baking qualities similar to 'Jewel' and canning qualities superior to 'Jewel' (1988

Received for publication 13 May 1991. Accepted for publication 16 Dec. 1991. Approved for publication by the Director of the Louisiana Agricultural Experiment Station as manuscript no. 91-285238. Supported by state and matching funds allocated to the Louisiana State Univ. Agricultural Center and the Louisiana Sweet Potato Advertising and Development Commission. The cost of publishing this paper was defrayed in part by the payment of page charges. Under postal regulations, this paper therefore must be hereby marked advertisement solely to indicate this fact.

${ }^{1}$ Assistant Professor, Dept. of Horticulture.

${ }^{2}$ Associate Professor, Sweet Potato Research Station, P.O. Box 120, Chase, LA 71324.

${ }^{3}$ Professor, Dept. of Plant Pathology and Crop Physiology.

${ }^{4}$ Professor, Dept. of Entomology.

${ }^{5}$ Specialist (Horticulture), Louisiana Cooperative Extension Service.

${ }^{6}$ Associate Professor, Dept. of Horticulture.

${ }^{7}$ Former Research Associate, Dept. of Horticulture. Current address: Dept. of Horticulture, North Carolina State Univ., Box 7609, Raleigh, NC 27695 . and 1989 National Sweetpotato Collaborators regional trials). Dry matter contents were $19.3 \%$ for 'Hernandez' and $26.3 \%$ for 'Jewel'. Flowering is adequate for breeding purposes, but it produces very few seeds.

\section{Disease and insect resistance}

'Hernandez' has an intermediate to resistant reaction to Fusarium wilt (Fusarium oxysporum Schlect. f. sp. batatas (Wallenw.) Snyd. \& Hans], similar to that of 'Centennial'. Reaction to southern root-knot nemataode [Meloidogyne incognita (Kofoid and White) Chitwood] is intermediate, similar to that of 'Jewel' and greater than 'Beauregard'. It is moderately resistant to soil rot [Streptomyces ipomoea (Person \& W.J. Martin) Waksman \& Henrici]; resistance is similar to that of 'Beauregard' and 'Travis' and superior to 'Jewel'. Yield and shape are not affected by severe soil rot conditions. 'Hernandez' also does not show symptoms to the viral disease internal cork. Storage roots are more resistant to bacterial root rot $(E r-$ winia chrysanathemi Burkholder, McFadden \& Dimock) than 'Jewel' or 'Beauregard'. It is more susceptible to the stem-rot reaction of $E$. chysanthemi than 'Jewel' or 'Beauregard'. Storage roots have intermediate resistance to fusarium root rot caused by Fusarium solani (Sacc.) Mart. emend. Snyd. \& Hans., similar to 'Jewel'. laborators regional trials. per acre.
'Hernandez' is moderately resistant to the white grub species Plectris aliena Chapin (1989 National Sweetpotato Collaborators regional trials), but is susceptible to another, Phyllophaga ephilida (Say.). It is more susceptible than 'Jewel' to the banded cucumber beetle (Diabrotica balteata Leconte); however, the dark skin masks some of the damage. It has intermediate levels of resistance to the sweetpotato flea beetle (Chaetoncnema confinis Crotch) when compared with resistant controls 'Regal' and 'Excel' (1989 National Sweetpotato Collaborators regional trials). Susceptibility to the wireworm, Diabrotica, Systena complex, is similar to 'Jewel' and 'Centennial'.

\section{Performance}

'Hernandez' has been evaluated for yield in the National Sweetpotato Collaborators Trial for 3 years (Table 1). Yields of 'Hernandez' were equal to or higher than those of 'Jewel' and were consistently higher than those of 'Centennial'. 'Hernandez' is a latedeveloping sweetpotato requiring 130 to 140 growing days. However, when planted early in the season, time to maturity is comparable to that of 'Jewel' (110 to 120 days). Productivity of 'Hernandez' is best in early plantings and at a $38-\mathrm{cm}$ plant spacing. 'Hernandez' is best in early plantings and at a 38-cm plant spacing. 'Hernandez' has excellent storage quality. Plant production from bedded roots is variable $(1987,1988$, and the 1989 National Sweetpotato Collaborators regional trials).

\section{Availability}

Limited quantities of foundation seed stock will be commercially available for the 1992 crop season. Requests for roots should be made to the Sweet Potato Research Station, P.O. Box 120, Chase, LA 71324.

Table 1. Marketable yields of 'Hernandez' and two other cultivars in the National Sweetpotato Col-

\begin{tabular}{llcccc}
\hline \hline & & \multicolumn{4}{c}{ Yield $\left(\mathrm{t} \cdot \mathrm{ha}^{-1}\right)^{\mathbf{z}, y}$} \\
\cline { 3 - 6 } Year & Cultivar & U.S. \#1 & Canner & Jumbo & $\begin{array}{c}\text { Total } \\
\text { marketable }\end{array}$ \\
\hline 1987 & Hernandez & 17.5 & 9.0 & 2.5 & 29.0 \\
& Jewel & 16.0 & 6.7 & 4.7 & 27.4 \\
& Centennial & 12.3 & 8.2 & 2.0 & 22.5 \\
& Hernandez & 13.7 & 7.2 & 2.5 & 24.3 \\
& Jewel & 13.3 & 6.3 & 2.6 & 22.2 \\
& Centennial & 8.1 & 5.4 & 1.9 & 15.4 \\
& Hernandez & 15.5 & 7.6 & 1.7 & 24.8 \\
& Jewel & 14.7 & 7.7 & 2.1 & 24.8 \\
& Centennial & 11.3 & 7.5 & 1.4 & 20.2 \\
\hline
\end{tabular}

${ }^{z}$ Averages from 11 locations in 1987 and 14 locations in 1988 and $1989 ; \mathrm{t}^{-h^{-2}} \times 0.446=$ U.S. tons

ySizes of roots: U.S. \#1: 5.1 to $8.9 \mathrm{~cm}$ diameter; 7.6 to $22.9 \mathrm{~cm}$ long; canner: 2.5 to $5.1 \mathrm{~cm}$ diameter; 5.1 to $17.8 \mathrm{~cm}$ long; jumbo: larger than either of the others, but marketable. 